\title{
Lower Jurassic ostracods from Ilminster, Somerset, England
}

\author{
IAN BOOMER \\ University of East Anglia \\ Norwich, NR4 7TJ.
}

\begin{abstract}
Pliensbachian and Toarcian ostracods are described from an interbedded marlstone/carbonate-mud -sequence in South-West England. Sediments of this age in other parts of Britain rarely offer a lithology favourable to the examination of calcareous microfossils. The fauna possesses similarities with other European sequences, particularly to the south. The presence of one species, Ektyphocythere dharennsourensis Boutakiout, Donze \& Oulmalch, 1982 suggests possible links with North-West Africa at this time. J. Micropalaeontol. 11 (1): 47-57, June, 1992.
\end{abstract}

\section{INTRODUCTION}

Roadworks in connection with the A303 Ilminster By-pass (Fig. 1) have revealed an alternating carbonate/argillite sequence which appears to span the uppermost Pliensbachian and most of the Toarcian. The sediments are generally fossiliferous and abundant ammonites have permitted the section to be accurately dated. The stratigraphical importance of this section becomes apparent when one looks at contemporary sediments on the nearby Dorset coastal section. There, the greater part of the Toarcian is represented by a condensed sequence, the Junction Bed (Cope et al. 1980).

The sediments, which apparently lack any anaerobic or dysaerobic conditions, have been the subject of an integrated lithological, micro/palaeontological study at University College London and the British Geological Survey. (Boomer et al. in press). An initial report on the ostracods of the section was given by the author in that work.

The only previously published works on British Toarcian ostracods are those of Bate \& Coleman (1975) from the East Midlands, Lord (1974) from the Down Cliff Clay, Dorset, Ainsworth (1986) from the Fastnet Basin and Boomer (1991) from the Mochras Borehole. The present lithology contrasts with the more extensive argillaceous sequences in other parts of Britain, therefore, any faunal differences observed may reflect the facies dependance of certain taxa.

\section{LITHOLOGY}

The sediments encountered at Ilminster are contemporary with the Middle and Upper Lias Junction Bed (sensu Wilson et al., 1958). The presence of microfossil rich marl bands within this section permits the first detailed chronostratigraphical and micro-biostratigraphical study of this interval, in full, in Britain. A detailed lithological description together with the stratigraphical distribution of ammonites, calcareous nannofossils, foraminifera and palynological remains are described elsewhere (Boomer et al.). The sediments represent the Junction-Bed Formation, which is composed of two members, namely the Barrington Beds Member (equivalent to the Junction-Bed of Howarth in Cope et al., 1980) and the Marlstone Rock Bed Member (equivalent to the Marlstone Rock-Bed of Howarth in Cope et al. 1980).

Due to the unfavourable lithology, only one horizon within the Marlstone Rock Bed Member was suitable for study. This was the oldest sample studied (ILM-KP 1) and was assigned to the spinatum zone, hawskerense subzone based on ammonite evidence. The remaining sixteen samples, all Toarcian, were from the Barrington Beds Member and range in age from tenuicostatum zone to the thouarsense zone.

The samples investigated are listed below and a brief lithological description is given for each. The sequence discussed is a composite of two separate sections, see location map (Fig. 1) and Fig. 2. Samples represent the entire thickness of each bed, except where otherwise stated e.g. ILM-9951/ILM-9950 \& ILM-9947.

Marlstone Rock Bed Member.

ILM-KP 1 Calcareous and in parts, marly sand contains occasional fragments of marly or bioclastic limestone. $10 \mathrm{~cm}$. Barrington Beds Member.

ILM-KP 2 Grey, marly, with shell debris laminae and occasional ferruginous nodules. $15 \mathrm{~cm}$.

ILM-KP 4 Grey to green marl. $3 \mathrm{~cm}$.

ILM-KP 3 Grey marl. $10 \mathrm{~cm}$.

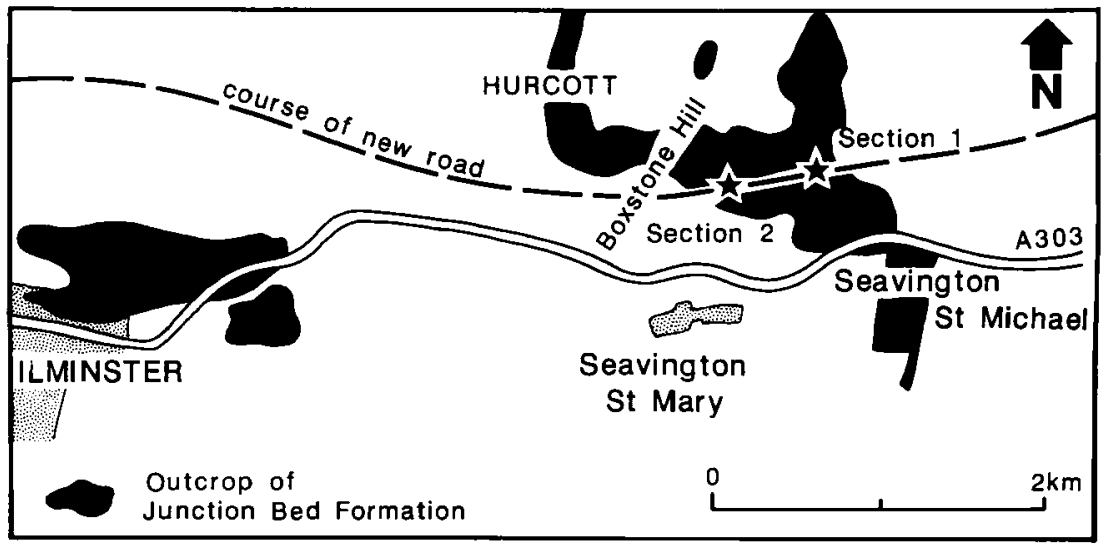

Fig. 1. Map showing location of Ilminster sections. 


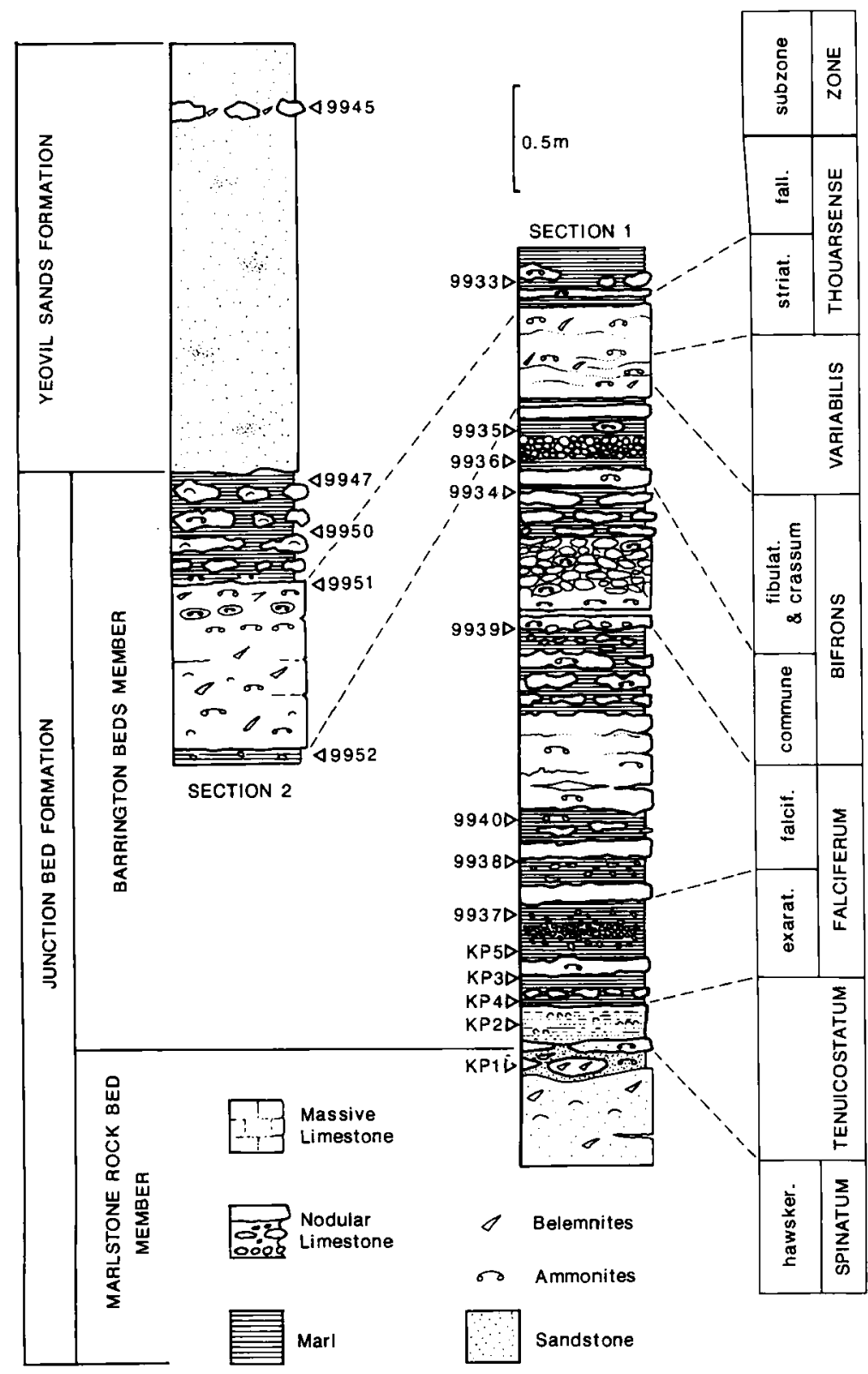

Fig. 2. Lithological sections at Ilminster and sampled horizons.

ILM-KP 5 \& ILM-9937 Grey marl with a band of < $1 \mathrm{~cm}$ sized limestone fragments in the middle of the bed. ILM-KP 5 from top of this bed, ILM-9937 from the bottom. $25 \mathrm{~cm}$.

ILM-9938 Grey marl with $<1 \mathrm{~cm}$ sized limestone fragments. $12 \mathrm{~cm}$.

ILM-9940 Grey marl with irregular/lenticular patches of argillaceous micrite. $15 \mathrm{~cm}$.

ILM-9939 Grey marl with $1-2 \mathrm{~cm}$ sized limestone nodules in common. $15 \mathrm{~cm}$.

ILM-9934 Sample taken from top of $30 \mathrm{~cm}$ section of interbedded grey marls and nodular argillaceous limestone.

ILM-9935 Grey marl with ammonites and limestone nodules. $7 \mathrm{~cm}$.

ILM-9933 Sample taken from the lowest part of a clay (weathered brown) passing vertically into a loamy soil. $20 \mathrm{~cm}$. The lowest $15 \mathrm{~cm}$ of this bed contains a discontinuous band of limestone nodules of varying size.

ILM-9952 Grey marl seam visible at the base of the section, thickness unknown.

ILM-9951/ILM-9950 \& ILM-9947 Dark grey clay with bands of lenticular limestone concretions. Black streaks occur near the jucntion with the overlying Yeovil Sands (ILM-9947). The basal 15cm contains abundant (mainly fragmented) ammonites and belemnites (ILM-9951). Sample ILM-9950 is from the middle of the bed.

ILM-9945 A distinctive band of widely spaced limestone nodules within the Yeovil Sands, which at this horizon become more silty. Belemnite and shell fragments common.

\section{OSTRACOD BIOSTRATIGRAPHY OF THE ILMINSTER SECTIONS.}

\section{Upper Pliensbachian}

The lowest sample investigated is characterised by the occurrence of species belonging to the genera Ogmoconcha and Ogmoconchella including vallate forms, assigned to the genus Hermiella by Kristan-Tollmann, (1977) but considered by the present author to belong to Ogmoconcha Triebel, 1941. These have been referred to as Tethyan forms of the genus Ogmoconcha due to their occurrence in the sediments of southern Germany (Malz, 1975; Lord \& Moorley, 1974), Portugal (Exton, 1979), Italy (Farinacci et al., 1979 and North Africa (Boutakiout et al. 1982, Maupin 1977, Maupin \& Vila 1976). These forms have now also been recorded, although in fewer numbers, from the Fastnet Basin (Ainsworth, 1986), Mochras Borehole, (Boomer, unpublished) and the Paris Basin (Bodergat \& Donze, 1988).

Other Ogmoconcha specimens from ILM-KP 1 possess carapaces with a bi-convex outline in dorsal view thus differentiating them from species attributed to the 'amalthei' and 'contractula' groups (Michelsen, 1975) which possess flattened lateral surfaces in dorsal view. O. convexa Boomer, 1991 originally recorded from the spinatum and tenuicostatum zones of the Mochras Borehole is one such species. The assemblage is similar to that recorded from the Ammonitico Rosso of the Appennines by Lord in Farinacci et al. 1979 and also to samples recovered from massive carbonate sediments at Djebel Zaghouan, Tunisia (Lord, pers. comm.). The present section differs, however, in that unlike the aforementioned sections both cytheracean and metacopine ostracods occur together.

A comparison with the Mochras section reveals that the ostracod assemblage from sample ILM-KP 1 is similar to samples of tenuicostatum zone age rather than those of spinatum age. This may be due to the distinctly different lithologies. ILM-KP 1 includes the youngest record of both Cytherelloidea anningi Lord, 1974, although only one specimen 

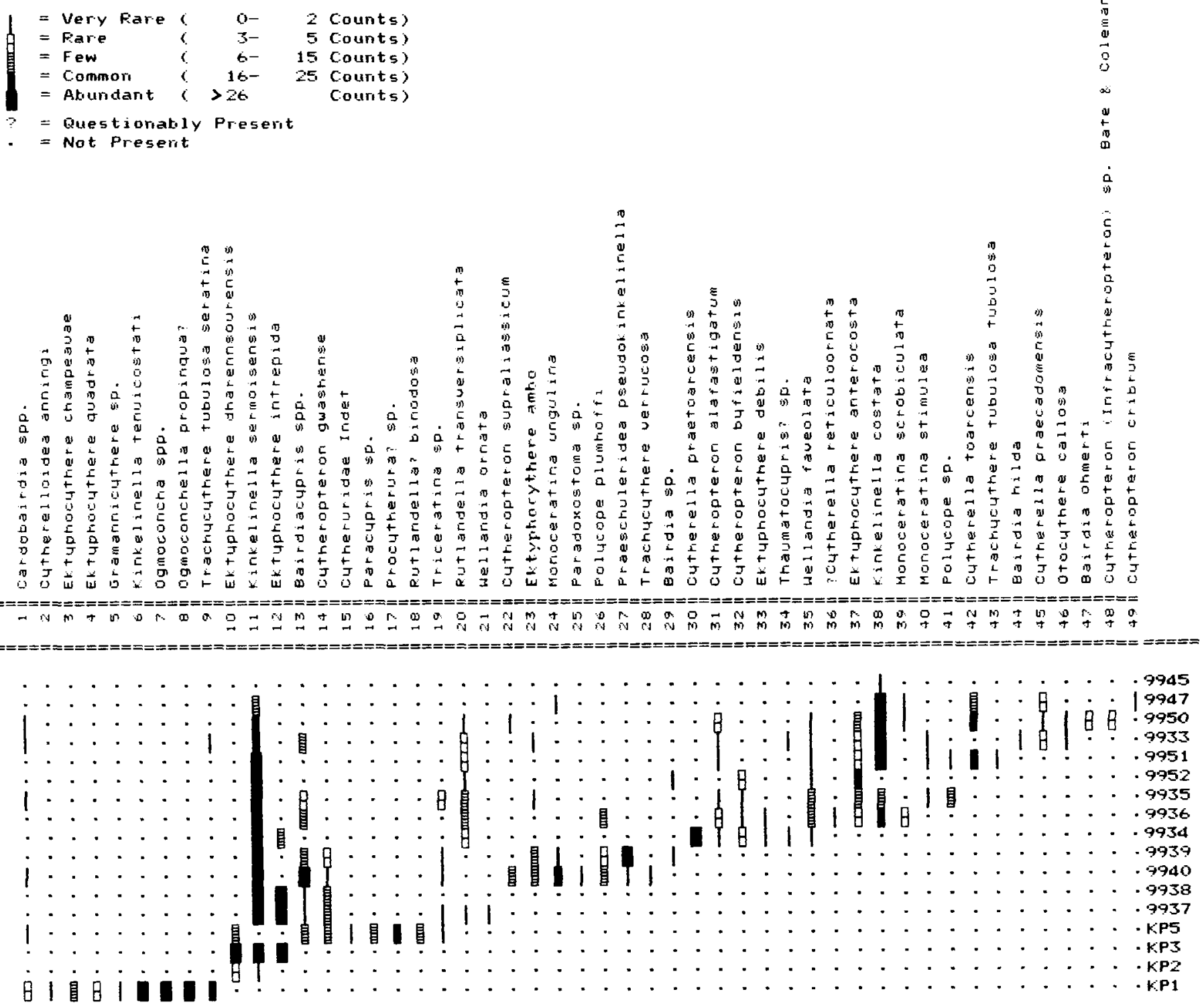

Fig. 3. Composite biostratigraphy of the Ilminster sequence. KP1, spinatum zone, hawskerense subzone; KP2 - 9937, falciferum zone, excavatum subzone; 9938-9939, falciferum zone, falciferum subzone; 9934, bifrons zone, commune subzone; 9936-9952, bifrons zone, fibulatum/crassum subzone; 9951-9947, thouarsense zone, fallacosum subzone; 9945, levesquei zone.

was recovered, and a few poorly preserved specimens of Ektyphocythere quadrata Boomer \& Lord, 1988. The low abundance and poor preservation of these specimens may indicate reworking. Specimens of Ektyphocythere tenuicostati (Martin, 1960), previously recorded from the spinatum zone of Portugal (Exton, 1979) and Germany (Martin, 1960), arecommon while a few valves of $E$. champeauae (Bizon, 1960) are also present.

\section{Lower Toarcian}

The succeeding sample (ILM-KP 2) marks a distinct faunal change with the disappearance of the Metacopina and a reduction in diversity from nine to two species. A similar faunal change occurs in the lowermost part of the falciferum zone, Lower Toarcian of the Mochras Borehole.
Ektyphocythere dharennsourensis (Boutakiout, Zone \& Oumalch, 1982), originally described from Morocco, is a large species (? $>1 \mathrm{~mm}$ ) with a distinctive outline in lateral view and strong sexual dimorphism. The species continues through the section to sample ILM-KP 5. Only in sample ILM-KP 3 are the male dimorphs present. ILM-KP 2 has the lowest occurrence of $E$. sermoisensis Apostolescu, 1959 the most abundant ostracod within the sequence and common in many European Toarcian sequences. The following sample (ILM-KP 3) marks the first appearance in the section of E. intrepida Bate \& Coleman, 1975. Sample ILM-KP 5 marks a recovery in ostracod diversity within the section to nine species. This is particularly due to the introduction of four cytherurid species, Procytherura sp. (represented only by A-1 instars), Cytheropteron gwashense Bate \& Coleman, 1975, Rutlandella sp. and Procytherura cf. P. 
mediocostata Bate \& Coleman, 1975. Furthermore, three further species are recorded, Bairdiacypris triangularis Ainsworth, 1986, Paracypris sp. together with a bythocytherid species Triceratina triassica Kozur, 1970 (Pl. 3. fig. 1) a species originally described from the Upper Anisian of Hungary. This species has not previously been recorded from Lower Jurassic sediments in Britain but does occur in the Middle Jurassic of the Cotswolds (Morris, 1983). Further specimens have been seen by the author in the collections of the Senckenberg Museum Frankfurt from. the Middle Jurassic sediments of Eastfield Quarry, South Cave, Yorkshire. The species has also been recorded from the Middle Jurassic of France (Depeche, 1985, p. 136, Pl. 31, fig. 14) and the Lower Jurassic of Germany (Knitter \& Reigraf, 1984, p. 69, Pl. 3, fig. 5).

Four of the aforementioned species are only recorded within this sample (see Fig. 3). The succeeding sample ILM-9937 sees the introduction of two more cytherurid species Rutlandella transversiplicata Bate \& Coleman, 1975 and Wellandia ornata Ainsworth, 1986 the former species being recorded throughout much of the succeeding sequence. ILM-9938 is dominated (50\%) by K. sermoisensis with no new species introduced while the following ILM-9940 is marked by the introduction of seven species including Ektyphocythere sp. A and Cytheropteron supraliassicum Herrig, 1969 previously recorded from Upper Liassic sediments throughout Germany and now from the Toarcian of South-West England (this work) and the Mochras Borehole, Wales (Boomer, unpublished). Praeschuleridea pseudokinkelinella Bate \& Coleman, 1975 is recorded from this and the succeeding sample, ILM-9939. Although this species possesses a similar lateral ornament to $E$. dharennsourensis it can be distinguished by its smaller size.

\section{Middle Toarcian}

Ten incoming taxa are recorded from samples ILM-9934 and ILM-9936. The lowest sample from the Middle Toarcian (ILM-9936) includes Cytherella praetoarcensis Boomer, 1991 and Cytheropteron byfieldensis Boomer \& Bodergat M.S. (in press) a species similar to C. alafastigatum Fischer, 1962 but distinguished by the coarse lateral punctation and the more robust nature of the carapace. This section is the type locality for E. anterocosta Boomer, 1988 which first occurs at the base of the fibulatum/ crassum subzone, Middle Toarcian, and continues into the Upper Toarcian. Sample ILM-9936 marks the first occurrence in the section of Kinkelinella costata Knitter, 1983. K. sermoisensis (Apostolescu) and K. costata (Knitter) are quite discrete species within this sequence. There does not appear to be any intermediate specimens between the former reticular species and the latter dominated by vertical ribbing. Furthermore, whereas $E$. sermoisensis is by far the most abundant species (46-70\%) in all but one sample from ILM-9937 to ILM-9935 (8 samples, lowest falciferum zone to uppermost bifrons zone) the succeeding four samples are dominated $(<55 \%)$ by $K$. costata with the former species constituting less than $20 \%$ of the fauna.

\section{Upper Toarcian}

The thouarsense zone assemblages are composed of species recorded from contemporary sediments elsewhere in Europe. The faunas are more closely allied to those recorded from France and Germany rather than from Mochras (Boomer, 1991 ) or the Fastnet Basin (Ainsworth, 1986 et seq.) with the incoming species including Cytherella toarcensis Bizon, 1960, Cytherella praecadomensis (Knitter \& Reigraf, 1983) and Otocythere callosa Triebel \& Klingler, 1959.

\section{FAUNAL CHANGE WITHIN THE SEQUENCE}

Fig. 4 shows that the rate of faunal change during the Toarcian reflects a relatively stable community given that these assemblages were recovered from marl bands which intercalate with 'limestone' horizons. The marked increase in extinctions, and concomitant decrease in diversity at the top of the section, reflects a facies change. It should be noted that only one specimen, probably reworked, was recorded from the youngest sample. Apart from the extinction of the Metacopina in the lowest part of the sequence there would not appear to be any distinct changes in the Toarcian ostracod fauna of South West Britain.

The most abundant superfamily is always represented by the Cytheracea except for the lowermost sample (KP1) which is dominated by the Healdiacea (Metacopina). The Most Abundant Species graph would indicate that the lowest Toarcian saw not only the disappearance of the Metacopina but also changes in the stability of the environment (i.e. ranging from 20-80\%). Subsequently the most abundant species, always cytheracean, generally constitutes $50-60 \%$ of the assemblage. This final graph would indicate a higher dominance figure than would be expected in a n open marine setting. The average value for the open marine Toarcian sequence in the Mochras section (Boomer, 1991) is $42 \%$. This may reflect a stressed environment under which these alternating limestone and argillaceous sediments were deposited.

\section{Explanation of Plate 1.}

(SP) indicates the use of Stereo-Pairs.

Figs 1, 4. Cytherella praecadomensis (Knitter \& Riegraf, 1984), Fig. 1a-b. (SP) ? RV, External, OS 13668, (UR thouarsense, ILM-9950), x71; Fig. 4a-b. (SP) ? LV, External, OS 13671, (Ur thouarsense, ILM-9950, x72.

Fig. 2a-b. Ogmoconchella sp. (SP) LV Adult, External, OS 13669, (Tenuicostatum, ILM-KP 1), x46

Fig. 3a-b. Ogmochonca sp.B. (SP) RV Adult (?), External, OS 13670, (Tenuicostatum, ILM-KP 1), x75.

Fig. 5a-b. Ogmoconcha inflata (Ainsworth, 1987) (SP) LV Adult, External, OS 13672, (Tenuicostatum, ILM-KP 1), x46.

Fig. 6a-b. Ogmoconcha sp.A. SP) RV Adult (?), External, OS 13673, (Tenuicostatum, ILM-KP 1), x74.

Fig. 7. Cytherella praecadomensis (Knitter \& Riegraf, 1984) LV Adult, External, OS 13674, (Ur thouarsense, ILM-9950), x71. Compare preservation of this specimen with Figs 1 and 4 (above) from the same sample suggesting the presence of reworking or sub-aerial erosion. Note also the possible predation boring in posterior third of valve.

Fig. 8. Cytherella praetoarcensis Boomer, 1991. ? CP, Left lateral, OS 13675, (Lr bifrons, ILM-9934), x65. PA 


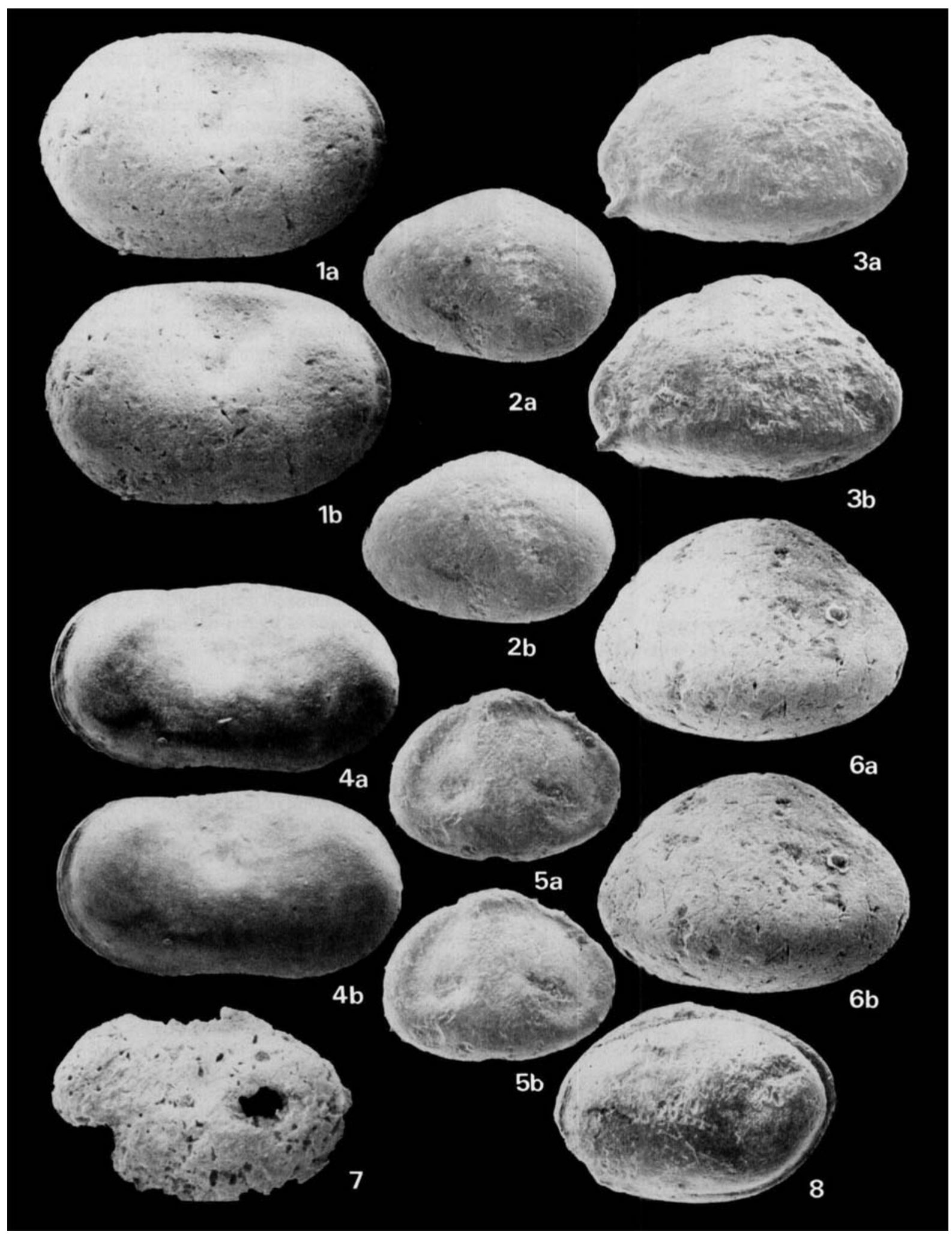




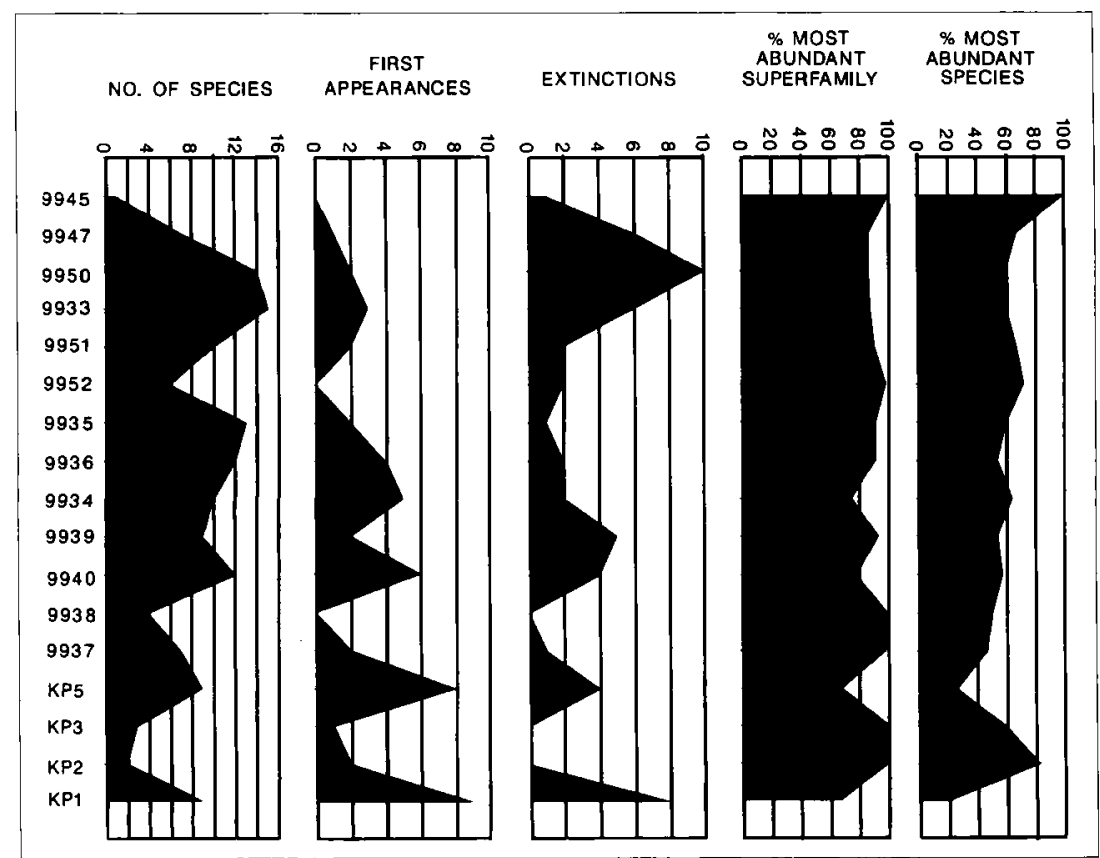

Fig. 4. This diagram displays the number of species in each sample together with the number of species making their first and last appearances in each sample. The two right hand graphs illustrate what percentage of each sample is represented by the most abundant superfamily (Healdiacea in lowest sample, Cytheracea thereafter) and finally what percentage of each sample is constituted by the single most abundant species (i.e. Dominance).

\section{COMPARISON WITH OTHER SECTIONS}

Many of the species recorded by Bate \& Coleman (1975) have been found in the present sections, the main exceptions being species attributed by those authors to the genera Procytherura, Camptocythere and Eucytherura. Direct biostratigraphical comparison between the present material and that from the East Midlands is not possible due to the absence, at Ilminster, of two of the zonal fossils designated by Bate \& Coleman (i.e. Camptocythere toarciana Bate \& Coleman and Kinkelinella persica Bate \& Coleman). The ranges of the two remaining zone fossils described by those authors ( $E$. intrepida and $E$. debilis) accord well with the present section. It should be noted that the ranges of these last two species, although apparently concurrent in both the East Midlands and Dorset, are much shorter than their total ranges recorded in the Mochras Borehole. This is true for many of the species recorded from these sites.

Although the Ilminster section has certain affinities with assemblages further to the south, there would appear to be no direct connection with either the Fastnet or Cardigan Bay Basins.
All specimens are deposited at the British Museum (Natural History), London.

\section{SYSTEMATIC DESCRIPTIONS}

Subclass Ostracoda Latreille, 1806 Order Podocopida Muller, 1894

Suborder Metacopina Sylvester-Bradley, 1961

Superfamily Healdiacea Harlton, 1933

Family Healdiidae Harlton, 1933

Genus Ogmoconcha Triebel, 1941

Ogmoconcha inflata (Ainsworth, 1987).

(Pl. 1, fig. 5)

1987 Hermiella inflata Ainsworth n.sp.; Ainsworth: 56, Pl.2, figs 15-17, text figs 1-2.

Remarks: The oldest sample investigated at Ilminster (ILM-KP 1) contained a mixed ostracod fauna of both Upper Pliensbachian and Lower Toarcian aspect. At least threespecies of Ogmoconcha are present in this sample, including some vallate forms assigned to Ogmoconcha inflata (Ainsworth). The other species, described below, (Ogmoconcha sp. A, $\mathrm{sp}$. B) are smooth shelled and without distinct marginal inflations. Certain ostracod assemblages from other parts of Europe are similar to that described here. Upper Pliensbachian faunas from the Apennines (Lord in Farinacci et al. 1979) are similar in the metacopine component of the assemblage. Contemporary faunas from Tunisia also possess comparable assemblages (Lord, pers. comm.).

Ainsworth (1987) described Hermiella inflata, from the Upper Pliensbachian of the Fastnet Basin and considered his new species to be conspecific with Ogmoconcha ambo Lord \& Moorley recorded by Exton (1979) from the Lusitanian Basin.

The two species described below are smaller than Ogmoconcha inflata, however, they are not considered to be juveniles of that species since the marginal inflations seen in suites of vallate healdiids in the collection of A.R. Lord, including Ogmoconcha $a m b o$, are distinctly developed as early as the A-3 instar.

Distribution. The spinatum and tenuicostatum zones of Mochras; Lower Toarcian, Paris Basin; Upper Pliensbachian/ Lower Toarcian, Fastnet Basin; Upper Pliensbachian, Lusitanian Basin.

Ogmoconcha sp. A.

(Pl. 1, fig. 6)

Material. Mochras, $25 \mathrm{CP}, 37 \mathrm{~V}$; Ilminster, $10 \mathrm{CP}, 28 \mathrm{~V}$.

\section{Explanation of Plate 2}

Figs 1-3. Ektyphocythere ambo sp. nov. Fig. 1a-b. (SP) ? LV, External, OS 136676, (Ur bifrons, ILM-9952), x71; Fig. 2. ?LV, Internal, OS 13677, (Ur falciferum, ILM-9939), x71; Fig. 3a-b. (SP) ? RV, External, OS 13678, (Ur falciferum, ILM-9939), x72.

Figs 4-6, 8, 9, 11. Ektyphocythere dharennsourensis Boutakiout, Donze \& Oumalch, 1982. Fig. 4a-b. (SP) ? LV, External, OS 13679, (Lr falciferum, ILM-KP 3), x7; Fig. 5a-b. (SP) ? CP, Right lateral, OS 13680, (Lr falciferum, ILM-KP 3), x46; Fig. 6. ? RV, External, OS 13681, (Lr falciferum, ILM-KP 5), x70; Fig. 8. ? LV, External, OS 13682, (Lr falciferum, ILM-KP 3), 46; Fig. 9. ? LV, Internal, OS 13683, (Lr falciferum, ILM-KP 3), x74; Fig. 11. ? RV, Internal, Detail of hinge, OS 13684, (Lr falciferum, ILM-KP 3), x375.

Figs 7, 10. Ektyphocythere anterocosta Boomer, 1988. Fig. 7. (Holotype) ? RV, External, OS 13277, (Ur thouarsense, ILM-9950), x72; Fig. 10 .? LV, External, OS 13281, (Ur thouarsense, ILM-9950), x66.

Fig. 12. Bairdia ohmerti Knitter, 1984. LV (A-1), External, OS 13685, (Ur thouarsense, ILM-9950), x86. 


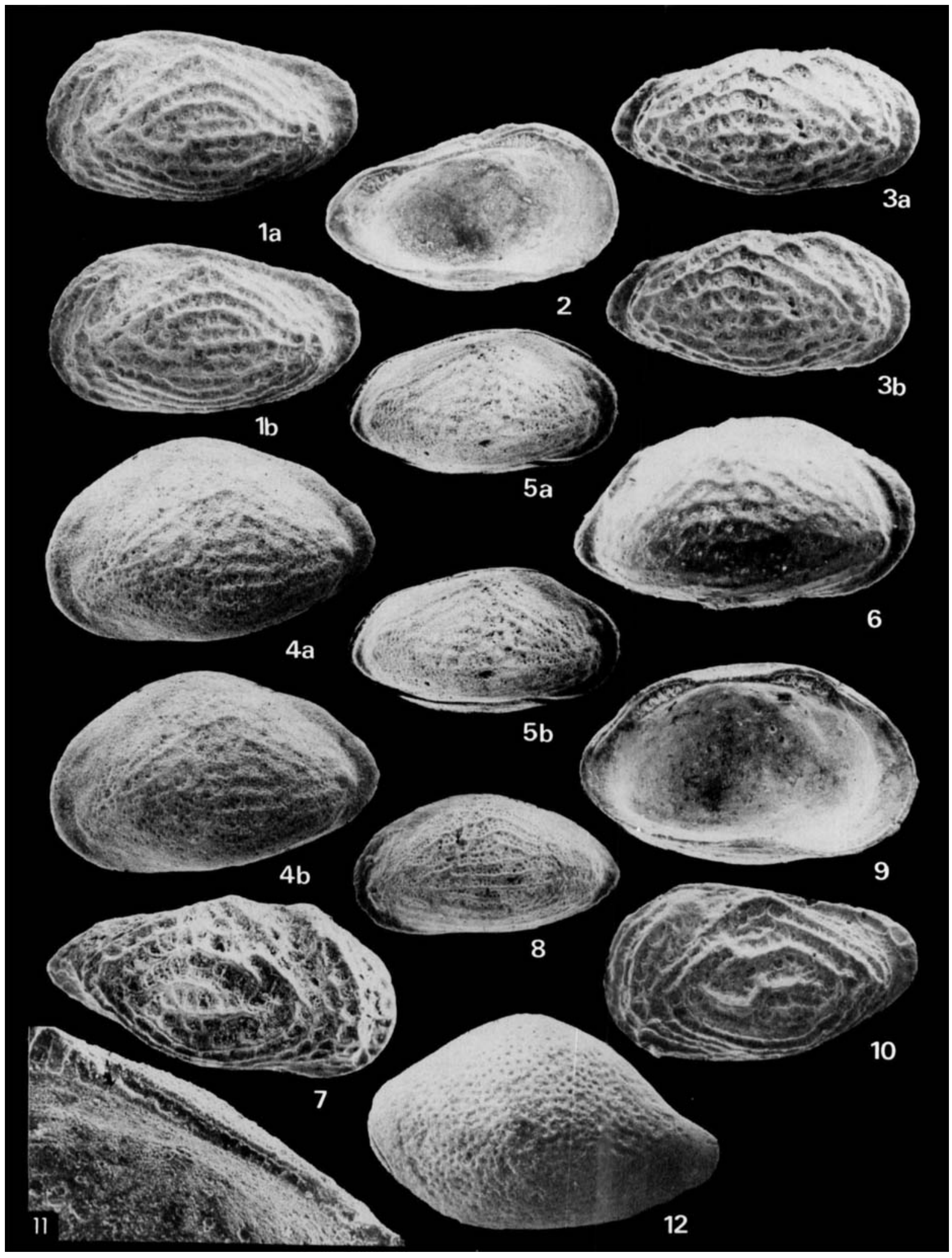


Remarks. A species of Ogmoconcha without the distinct marginal inflations of species such as $O$. ambo and $O$. inflata but with a definite ventro-lateral swelling on each valve, thus implying a relationship to the vallate forms. The lateral swellings give the carapace a sub-triangular outline in anterior view. In lateral view the carapace has a triangular oval outline with a convex ventral margin. Steeply rounded anterior and posterior margins converge at the greatest height just anterior of the mid-length. This species is distinguished from O. convexa (Boomer, 1991) by the different outline in anterior view, the latter species having a strongly convex oval outline. A similar species was figured by Knitter \& Riegraf (1983, Pl. 4, fig. 3) from the Upper Pliensbachian of SW Germany. Although that material was assigned to O. circumvallata Dreyer, 1965 the figured specimen is quite different from the holotype figured by Dreyer (1965, Pl. 1, fig. 4; Pl. 2, figs 1-4). A similar species was also figured by Bodergate \& Donze, 1988. This species is left in open nomenclature due to the lack of well preserved internal details, particularly the muscle adductor scars. Furthermore, few of the recorded specimens are adult valves thus making difficult a comprehensive comparison with other species.

Distribution. Uppermost spinatum zone (uppermost Pliensbachian) and tenuicostatum zone (Lower Toarcian) at Mochras and sample ILM-KP 5(Upper Pliensbachian or Lower Toarcian) at Ilminster.

\section{Ogmoconcha sp. B}

(Pl. 1, fig. 3)

Material. Ilminster, $8 \mathrm{~V}$.

Remarks. This species possesses a large postero-ventral spine similar to the specimen figured by Riegraf (1985; Pl. 1, fig. 16) as Ogmoconcha rotunda Dreyer, 1967. The outline and shape of the present material is very close to that of Ogmoconcha sp. A the main difference being the presence of the postero-ventral spine. Lord in Farinacci et al. 1979 recorded similar specimens from the Upper Pliensbachian of Strettura in the Italian Apennines. Material deposited with the British Museum (Natural History) and in the personal collection of A.R. Lord, collected by R.H. Bate from the Pliensbachian of Djebel Zaghouan, Tunisia also bears similarities to the present material. The Southern European and North African material differs in that they possess a more pronounced ventro-lateral inflation with a greater degree of antero- and postero-marginal compression with respect to the British material.
Distribution. Present in the lowest sample from Ilminster with similar material recorded from contemporary levels in southern Europe.

Suborder Platycopina Sars, 1866

Family Cytherellidae Sars, 1866

Genus Cytherella Jones, 1850

Cytherella praecadomensis (Knitter \& Riegraf, 1984)

(Pl. 1, figs 1, 4)

1984 Cytherelloidea praecadomensis Knitter \& Riegraf p. 67, P1. 4, figs 2,3 .

1986 Cytherella? depressum sp. nov. Ainsworth p. 291, Pl.1, figs 14-19.

Material. Mochras, $17 \mathrm{CP}, 40 \mathrm{~V}$; Ilminster $7 \mathrm{CP}, 15 \mathrm{~V}$.

Remarks. The carapace is more robust than in Cytherella cadomensis (Bizon) which possesses distinct marginal inflations. The deep muscle sulcus is a very distinctive feature which exaggerates the marginal inflation. The females appear to possess only one posterior swelling and therefore this species, as with the descendant $C$. cadomensis (Bizon), is assigned to Cytherella. Cytherella? depressum Ainsworth, 1986 is considered to be a junior synonym of the present species.

Distribution. Recorded in the thouarsense zone of Ilminster and mid-bifrons to uppermost variabilis zone at Mochras (Boomer, unpublished). Although only recently described, this species appears to be geographically widespread in the Middle and Upper Toarcian sediments across North-West Europe.

\author{
Suborder Podocopina Sars, 1866 \\ Superfamily Cytheracea Baird, 1850 \\ Family Protocytheridae, Ljubimova, 1955 \\ Subfamily Kirtonellinae Bate, 1963 \\ Genus Ektyphocythere Bate, 1963
}

Ektyphocythere dharennsourensis Boutakiout, Donze \& Oulmalch, 1982

(Pl. 2, figs 4-6, 8, 9, 11)

1975 Ektyphocythere dharennsourensis Boutakiout et al. p. 97, Pl. 1 , figs 9, 10; Pl. 2, figs 1-6.

Material. Ilminster, $35 \mathrm{CP}, 61 \mathrm{~V}$.

Remarks. This large species displays marked sexual dimorphism and is easily recognised. Prior to the present study the species had only been recorded from Lower and Middle Toarcian sediments, at the type locality, to the West of Fez, Morocco. Lord (1988) in his review of the Tethyan distribution of Lower Jurassic Ostracods suggested that the

Explanation of Plate 3

Fig. 1a-b. Triceratina sp. (SP) LV Adult, External, specimen lost, (Mid-bifrons, ILM-9936), x73.

Fig. 2. Wellandia faveolata Bate \& Coleman, 1975. RV Adult, External, OS 23686, (Mid-bifrons, ILM-9936), x147.

Fig. 3a-b. Ektyphocythere champeauae (Bizon, 1960). (SP) LV Adult, External, OS 13687, (Tenuicostatum, ILM-KP 1), x73.

Fig. 4a-b. Rutlandella? sp. (SP) LV Adult, External, OS 13688, (Lr falciferum, ILM-KP 5), x159.

Fig. 5a-b. Cytheropteron byfieldensis Boomer \& Bodergat in-press. (SP) LV Adult, External, OS 13689, (Lr bifrons, ILM-9934), x85.

Fig. 6a-b. Procytherura? sp. (SP) RV Adult (?), External, OS 13690, (Lr falciferum, ILM-KP 5), x159.

Fig. 7, 9. Pra eschuleridea pseudokinkelinella Bate \& Coleman, 1975. ? LV, External, OS 13691, (Ur falciferum, ILM-9939), x73; Fig. 9. ? RV, External, OS 13693, (Ur falciferum, ILM-9939), x72.

Fig. 8. Cytheroipteron alafastigatum Fischer, 1962. LV Adult, External, OS 13692, (Ur thouarsense, ILM-9950), x84.

Fig. 10. Bairdiacypris sp. RV Adult (?), External, OS 13694, (Ur falciferum, ILM-9940), x71. 


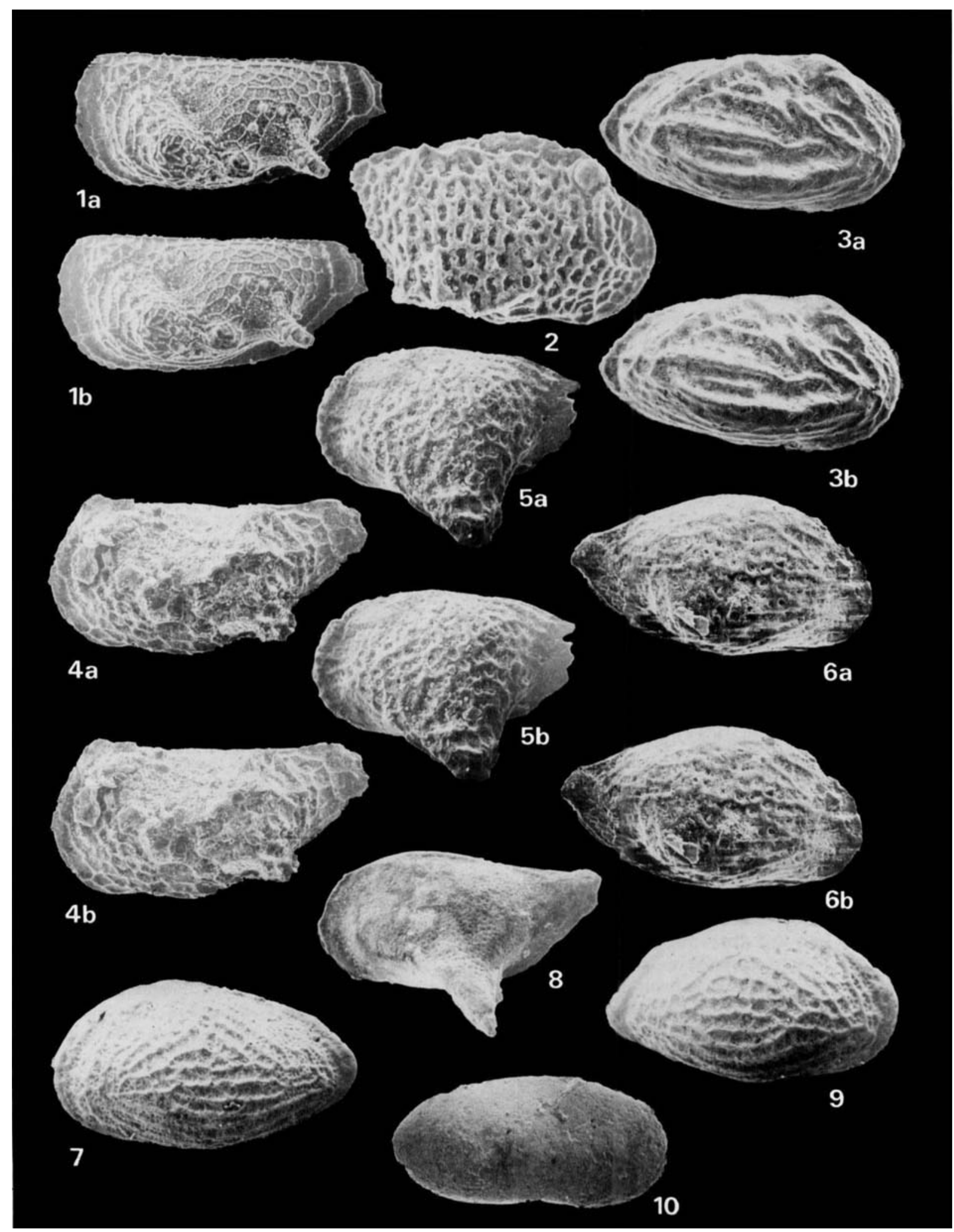


dating of these sediments may be incorrect: the presence of the genus Marslatourella, previously only recorded from Middle Jurassic strata, supporting this theory. The present study further supports a Lower Jurassic age for the Moroccan material. The species bears similarities to Praeschuleridea pseudokinkelinella Bate \& Coleman. The latter species, however, is neither as large as, nor does it display the marked dimorphism seen in $E$. dharennsourensis. Examination of the marginal zone reveals between twelve and fifteen simple straight marginal pore canals anteriorly and four to five posteriorly contrasting with the typical pattern in Ektyphocythere where the maximum numer anteriorly is about ten.

The nature of the dimorphism and distribution of anterior marginal pore canals is similar to that observed in Praeschuleridea, however, the present species appear to possess an antimerodont hinge typical for Ektyphocythere. The present material has been retained within the latter genus due to the poorly preserved nature of the hingement and the form of the external ornament. It is possible, however, that this species may represent an intermediate stage between Ektyphocythere and Praeschuleridea.

Distribution. The species is recorded in the falciferum zone of Ilminster, Lower and Middle Toarcian of Morocco

\section{Ektyphocythere ambo sp. nov.}

(Pl. 2, figs 1-3)

1975 Ektyphocythere intrepida Bate \& Coleman in part. p. 20, Pl. 7, fig.4.

non 1975 Ektyphocythere intrepida Bate \& Coleman p. 20, Pl. 7, figs 1-3, 5, 8-10; Pl. 8, figs 7, 8 .

Derivation of name. From the greek ambon meaning rim, referring to the postero-dorsal rim of the left valve in this species which distinguishes it from similarly ornamented, contemporary taxa.

Diagnosis. A species of Ektyphocythere Bate (1963) with well developed open reticulation dominated by longitudinal elements. The species possesses a more dorsally extended postero-dorsal margin than that of other Ektyphocythere species. Holotype. Left valve, OS 13676.

Material. Mochras, $5 \mathrm{CP}, 12 \mathrm{~V}$; Ilminster, $18 \mathrm{~V}$.

Type locality and Horizon. Ilminster $\left(55^{\circ} 55^{\circ} 0^{\prime \prime} \mathrm{N}, 2^{\circ} 55^{\prime} 0^{\prime \prime} \mathrm{W}\right)$, Sample ILM-9952, Upper bifrons Zone, Middle Toarcian.

Description. An oval carapace in lateral outline similar to $E$. intrepida Bate \& Coleman, distinct dimorphism is apparent with the males somewhat more elongate and particularly notable for the poster-dorsal flange in the left valves which is a much stronger feature than in the females. Both anterior and posterior margins are rounded, the latter more narrowly so. In dorsal view the outline is moderately inflated with the maximum width just behind the mid-length. The greatest height is at the anterior cardinal angle, dorsal margin is straight in the right valve and slightly concave in the left valve due to the presence of the postero-dorsal flange referred to above. Ventral margin slightly sinuous. Left valve overlaps the right dorsally especially at the cardinal angles, also in the mid-ventral area. Weak eye swelling present below the anterior cardinal angle.

Ornament typical for the genus but the present material is characterised by strong secondary cross ribbing producing a coarse reticulation in the mid-valve region. The inner lamellae is fused throughout, broad anteriorly moderate ventrally and posteriorly. Hinge is antimerodont, muscle scars indistinct but appear to represent a crescentic row of four adductor scars, the frontal scars are not clearly observed. Marginal pore canals not seen.

Remarks. A species of Ektyphocythere which bears a strong resemblance to $E$. intrepida Bate \& Coleman. The presence of a postero-dorsal flange is the main difference between this species and $E$. intrepida Bate \& Coleman. It must be noted, however, that the two species have not been found in the same sample at Ilminster (see Fig. 3). The current author believes that one example of this species was figured in the type description of E. intrepida (op.cit. 1975; Pl. 7, fig. 4). The species is distinguished by the stronger development of secondary cross-ribs than is seen in E. intrepida producing a more strongly reticulate pattern.

Distribution. Uppermost falciferum and lower bifrons at Mochras, falciferum and bifrons zones of the East Midlands and falciferum to thouarsense zones, Ilminster.

\section{CONCLUSIONS}

The lowest sample examined (ILM-KP1) although assessed as spinatum zone (Upper Pliensbachian) on the basis of ammonites, has an ostracod fauna similar to that of tenuicostatum zone assemblages (Lower Toarcian) from the Mochras Borehole. The succeeding samples, particularly in the falciferum and bifrons zones, bear a strong correlation with those described by Bate \& Coleman (1975) from the Lower and Middle Toarcian of the East Midlands. Stratigraphical ranges of certain species at the English sites are, however, much shorter than the total ranges recorded from the extensive sequence at Mochras. Furthermore the lowest sample contains an assemblage which may indicate a certain degree of reworking. Indeed, some samples higher up the section include badly dissolved specimens, also possibly indicative of erosion/ reworking (see Pl. 1, figs 1, 4, 7).

It is important to note that despite the lithological differences between Ilminster and the East Midlands section, the faunal similarities are quite strong. However, the present material would suggest that the Fastnet and Cardigan Bay Basins to the West are systems quite distinct from other parts of Britain as reflected in the facies differences. There would appear to be a strong palaeoceanographical link with parts of southern Europe and North Africa at certain times, particularly so in the lowest Toarcian. This may be due to changes in sea-level and/or the inception of new pathways bringing Tethyan forms further North. Records of vallate forms of Ogmoconcha in the uppermost Pliensbachian and lowest Toarcian of North West Europe would support such an idea. These species are considered to be essentially Tethyan in their distribution. Indeed during the Upper Triassic, ornamented Healdiids often dominated marine ostracod assemblages from Eastern Europe through the Tethyan region into what is now South-East Asia. It should also be noted that specimens of Oligocythereis? mochrasensis from the Pliensbachian of the Mochras Borehole have been recorded from D.S.D.P. site 547 of northwestern Africa (Boomer, 1991). The section at Ilminster therefore details the evolution of 
ostracod faunas in Southern England during the Toarcian and implies an increased influence from Tethys in the earliest Toarcian.

\section{ACKNOWLEDGEMENTS}

I wish to thank Dr Alan Lord for his supervision during the course of this work, Mr J. Davy (UCL) and Mr P. Judge (UEA) for technical assistance and the following for field assistance, Dr K. Page (NCC), Dr P. Bown (UCL) and Dr L. Gallagher (Palaeoservices). The financial support of The Department of Education for Northern Ireland and University College London is acknowledged.

\section{Manuscript received April 1991 \\ Revised Manuscript accepted February 1992}

\section{REFERENCES}

Ainsworth, N.R. 1986. Toarcian and Aalenian Ostracoda from the Fastnet Basin, offshore South-West Ireland, Geol. Surv. Ire. Bull. 3, 277-336, Pls 1-11.

Ainsworth, N.R. 1987. Pliensbachian Ostracoda from the Fastnet Basin, offshore southwest Ireland. Geol. Surv. Ire. Bull. 4, 41-62, Pls 1-2.

Apostolescu, V. 1959. Ostracodes du Lias du Bassin de Paris. Rev. Inst. Fr. Pet. Paris. 14, 795-826, Pls 1-3.

Bate, R.H. \& Coleman, B.E. 1975. Upper Lias Ostracoda from Rutland and Huntingdonshire. Bull. Geol. Surv. G.B. London. 55, 1-42, Pls 1-15.

Bizon, J.J. 1960. Sur quelque Ostracodes du Lias de Bassin de Parisien. Rev. Micropaleont. 2, 203-211, Pls 1-3.

Bodergat, A.-M. \& Donze, P. 1988. Biostratigraphical scale in the Toarcian of the Paris Basin (France) by means of Ostracod Associations. In: Hanai, T., Ikeya, N.\& Ishizaki, K. (Eds), Proceedings of the Ninth International Symposium on Ostracoda. Evolutionary Biology on Ostracoda. 1261-1267, Pl. 1. Kodansha Ltd., Tokyo, Japan.

Boomer, I.D. 1988. On Ektyphocythere anterocosta Boomer sp. nov. A stereo-Atlas of Ostracod Shells. London 93-96.

Boomer, I.D. 1991. Ostracod biostratigraphy of the Mochras Borehole, J. Micropalaeont. 9 (2), 205-218.

Boomer, I.D. \& Bodergat, A.-M. in press. On Cytheropteron byfieldensis Boomer \& Bodergatsp. nov. A Stereo-Atlas of Ostracod Shells. London.

Boomer, I.D., Brown, P.R., Lord, A.R., Lowry, F.M.D., Page, K. \& Riding, J. (in press). The Stratigraphy of the late Pliensbachian/ Toarcian (Lower Jurassic) sequence at Ilminster, Somerset. Geol. Mag.

Boomer, I.D. \& Lord, A.R. 1988. On Ektyphocythere quadrata Boomer, sp. nov. AA Stereo-Atlas of Ostracod Shells. London 85-88.

Boutakiout, M., Donze, P. \& Oumalch, F. 1982. Nouvelles especes l'ostracodes du Lias moyen et superieur du Jbel Dhar Nsour (Rides sud-rifaines, Maroc Septentrional). Rev. Micropaleont. 25, 94-104, Pls $1-2$.

Cope, J.C.W., Getty, T.A., Howarth, M.K., Morton, N. \& Torrens, H.S. 1980. A correlation of Jurassic rocks in the British Isles, Part One: Introduction and Lower Jurassic. Geol. Soc. Lond., Special Report No. 14, 1-73.

Depeche, F. 1985. Lias superieur, Dogger, Malm. In: Oertli, H.J. (Ed.) Atlas des Ostracodes de France. Bull. Centres, Rech. Explor.-Prod. Elf-Aquitaine Mem. 9, 119-145, Pls 27-35.
Dreyer, E. 1965. Mikrofossilien des Rat und Lias von SW Brandenburg. Jb. Geol., 1 (1967) 491-531, Pls 1-9, Berlin.

Exton, J. 1979. Pliensbachian and Toarcian microfauna of Zambujal Portugal: Systematic Paleontology. Geol. Paper Carleton Univ. 79 (1), 1-104, Pls 1-16.

Farinacci, A., Lord, A.R., Pallini, G. \& Schiavinotto, F. 1979. The depositional environment of the Domerian-Toarcian sequence of Strettura (Umbria). Geol. Romana. 17 (1979) 303-323.

Knitter, H. 1983. Biostratigraphische untersuchungen mit ostracoden in Toarcien Suddeutschlands. Facies 8, 213-262, Pls 1-7.

Knitter, H. \& Reigraf, W. 1984. Biostratigraphie (Cephalopoden Ostracoden) des Oberen Toarcian von Blumberg-Achdorft/Wutach und Weilheim/Teck (Baden-Wurttemburg). Jahrb. Geol. Landes. Baden-Wurtt. 26, 57-97, Pls 1-5.

Kozur, H. 1970. Neue ostracoden-arten aus dem obersten Anis des Bakonyhochlandes (Ungarn). Ber. Nat-Med Ver. Innsbruck 58, 384-428.

Kristan-Tollmann, E. 1977. Zur evolution des schliessmuskel feldes bei Healdiidae und Cytherellidae (Ostracoda). N. Jb. Geol. Palaont. Mh. 20, 621-639.

Lord, A.R. 1974. Ostracods from the Toarcian of England. Palaeontology. 17 (3), 599-622, $1 \mathrm{Pl}$

Lord, A.R. 1988. Ostracoda of the Early Jurassic Tethyan Ocean. In: Hanai, T., Ikeya, N. \& Ishizaki, K. (Eds), Proceedings of the Ninth International Symposium on Ostracoda. Evolutionary Biology of Ostracoda. 1261-1267. Pl. 1. Kodansha Ltd., Tokyo, Japan

Lord, A.R. \& Moorley, A. 1974. On Ogmoconcha ambo Lord \& Moorley sp. nov. A Stereo-Atlas of Ostracod Shells. 2 (3), 9-16.

Malz, H. 1975. Eine Entwicklungsreihe "vallater" Ogmoconchen (Ostracoda) im S-deutschen lias. Senckenberg leth. 55, 485-503, Pls $1-3$.

Martin, G.P.R. 1960. In: Hoffman, K. \& Martin, G.P.R. Die zone des Dactylioceras tenuicostatum Toarcian, Lias) in NW und SW Deutschland. Zeit. Palaont. 34, 103-249, Pls 1-2.

Maupin, C. 1977. Donnees micropaleontologiques nouvelles et precisions stratigraphique sur le Lias du Kef Ben Chikr Bon Rouhou et du Kef Toumiette Nord (Chaine calcaire kabyle - Nord du Constantinous - Algerie). Rev. Micropaleont. 20, 91-99, Pls 1-2.

Maupin, C. \& Vila J.-M. 1976. Microfossiles du lias superieur au Djebel Youssef (Hautes Plaines Setifiennes Algerie). Rev. Micropaleont. 19, 162-165, 1 Pl.

Michelsen, O. 1975. Lower Jurassic biostratigraphy and Ostracods of the Danish Embayment. Danm. geol. Unders. Copenhagen. 104, $1-289$, Pls $1-42$.

Morris, P.H. 1983. Palaeoecology and Stratigraphic distribution of Middle Jurassic ostracods from the Lower Inferior Oolite of the Cotswolds, England. Palaeogeogr., Palaeoclimatol. Palaeoecol. Amsterdam. 41,, 289-324, Pls 1-11.

Riegraf, W. 1985. Microfauna, Biostratigraphie und Fazies im unteren Toarcium Sudwestdeutschlands und Vergleiche mit benachbarten Gebeiten. Tubinger Micropalaontologtische Mitteilungen. 3, 1-232, Pls 1-12.

Stoermer, N. \& Winholz, E. 1967. Mikrobiostratigraphie an der Lias/ Dogger-Grenze in Bohrungen nordlich der Mitteldeutschen Hauptscholle. Jb. Geol. 1 (1965), 533-591, Pls 1-10.

Triebel, E. \& Klingler, W. 1959. Neue Ostracoden Gattung aus dem deutschen Lias. Geol. Jb. 76, 335-372, Pls 1-9.

Wilson, V., Welch, F.B.A., Robbie, J.A. \& Green, G.W. 1958. Geology of the country around Bridport and Yeovil. Mem. geol. Surt. G.B (1959), 239pp. 7 Pls. 